\section{Komunitas Muda Urban Mengelola Sampah: Kajian Partisipatoris Gerakan Peduli Sampah Nasional di Kota Yogyakarta}

Oleh :

\section{Adityo Nugroho ${ }^{1}$}

\begin{abstract}
Abstrak
Beberapa komunitas muda urban di Yogyakarta berkolaborasi dalam Aliansi Komunitas Yogyakarta menginisiasi suatu gerakan lingkungan dengan nama Peduli Sampah Nasional (PESAN) 2017. Kajian ini menjelaskan bagaimana gerakan itu ditujukan untuk meningkatkan kepedulian masyarakat terhadap ancaman pencemaran sampah yang mengancam lingkungan hidup dan keseimbangan ekologis. Melalui pendekatan partisipatoris dan analisis kualitatif, kajian ini dilakukan berdasarkan dua aksi kegiatan dalam gerakan ini. Gerakan PESAN 2017 dibagi menjadi dua kegiatan. Kegiatan pertama dimaksudkan untuk memberi edukasi kepada siswa-siswa Sekolah Menengah Atas (SMA) tentang pentingnya pengelolaan sampah. Kegiatan kedua merupakan aksi bersih sampah di bantaran Kali Gajah Wong. Kegiatan ini juga bertujuan untuk mendidik masyarakat yang tinggal di sekitar sungai dalam menangani metode sanitasi dan pengelolaan sampah.
\end{abstract}

Kata kunci: gerakan lingkungan, komunitas muda urban, pengelolaan sampah berbasis komunitas

\footnotetext{
Abstract

A number of urban youth communities in Yogyakarta have worked in a collaborative project of the 'Aliansi Komunitas Yogyakarta' (Yogyakarta Community Alliance) and they initiated an

1 Adityo Nugroho adalah manajer komunitas Padepokan ASA Wedomartani, Yogyakarta. Penulis juga aktif sebagai penggiat komunitas muda di Yogyakarta.
}

environmental movement called 'PESAN 2017' which stands for community waste management. The movement aimed to invoke people's concerns on waste management esepecially due to waste pollution that may threat the environment and ecological ballance. The study was conducted in a participatory approach and qualitative analysis based on two activities of the movement. The PESAN 2017 movement consisted of two main activities. The first activity was aimed to provide an education for high school's students in Yogyakarta about the importance of waste management. The second activity was conducted by cleaning up Gajah Wong riverbank from wastes or trashes. The last activity was also aimed at educating people who live surrounding the river in dealing with sanitary method and waste management.

Keywords: environmental movement, urban youth, community waste management

\section{Pengantar}

Yogyakarta merupakan salah satu pusat pendidikan di Indonesia. Sebagai salah satu pusat pendidikan maka beberapa perguruan tinggi negeri dan swasta tumbuh subur di seputaran wilayah administrasi kota Yogyakarta serta sebagian wilayah kabupaten Sleman dan Bantul. Banyaknya perguruan tinggi sejalan dengan banyaknya kaum muda yang memilih Yogyakarta sebagai tempat untuk menimba ilmu. Baik itu mereka yang berasal dari wilayah propinsi Daerah Istimewa Yogyakarta ataupun dari daerah lain di Indoneia. Kondisi terkini di lapangan memperlihatkan banyaknya rumah singgah atau kos-kosan yang menjamur di berbagai titik di 
Jurnal Pemikiran Sosiologi Volume 4 No. 1, Januari 2017

Adityo Nugroho

Komunitas Muda Urban Mengelola Sampah:

Kajian Partisipatoris Gerakan Peduli Sampah Nasional di Kota Yogyakarta

Yogyakarta, terutama di sekitaran wilayah perguruan tinggi tersebut dibangun. Sebuah bukti nyata banyaknya kaum muda dari daerah lain yang menuntut ilmu di Yogyakarta.

Menilik kembali pada keberadaan kaum muda sebagai pelajar di perguruan tinggi, bahwa belajar adalah tujuan utama mereka berada di Yogyakarta. Namun satu pertanyaan besar mengemuka, apa yang dilakukan para kaum muda ini ketika tidak dalam kegiatan belajar di kampus mereka masing-masing. Jawaban beragam akan muncul mulai dari hanya berdiam diri, menghabiskan waktu untuk bersenangsenang, bekerja paruh waktu, membina hubungan dengan lawan jenis, ataupun menjadi bagian dari sebuah komunitas. Jawaban terakhir tentu menarik, menjadi bagian dari sebuah komunitas adalah salah satu pilihan positif bagi mereka. Komunitas mampu menjadi wadah bagi kaum muda untuk menyalurkan hobi ataupun passion yang mereka miliki. Komunitas-komunitas ini didirikan oleh anak-anak muda, anggota yang kesemuanya merupakan anak muda, dan berbagai kegiatan serta gerakan pun diinisiasi oleh anak muda. Maka bisa dikatakan bahwa sekumpulan anak muda ini merupakan komunitas muda. Lebih spesifik karena posisi komunitas muda ini berada di wilayah perkotaan maka mereka bisa disebut sebagai komunitas muda urban. Jumlah mereka ada ratusan dan sebagian besar dari mereka terwadahkan dalam sebuah naungan bernama Forum Yogyakarta Peduli. Tercatat ada berbagi jenis fokus kajian komunitas muda urban yang tersebar di Yogyakarta, mulai dari komunitas pendidikan, kemanusiaan, lingkungan, olahraga, seni budaya, dan lainlain. Berbagai kajian dari masing-masing komunitas muda urban ini menunjukan spesifikasi serta bidang utama yang digarap oleh komunitas yang bersangkutan. Kajian yang dilakukan oleh masing-masing komunitas muda urban dilandaskan atas fenomena sosial yang ada di sekeliling mereka. Pada konteks ini maka kajiankajian yang diambil komunitas muda urban di Yogyakarta juga berkutat pada fenomena sosial yang ada di wilayah administrasi Yogyakarta dan sekitarnya. Misalnya saja tentang pendidikan anak-anak pinggiran, kepedulian lingkungan hidup, gerakan kemanusiaan, pelestarian budaya, dan lainlain.

Di Yogyakarta sendiri berbagai fenomena sosial muncul dan berkembang. Seperti halnya kota-kota besar lain di Indonesia, fenomena-fenomena yang muncul merupakan dampak dari semakin kompleksnya kehidupan di perkotaan. Salah satu yang menyeruak adalah dampak lingkungan yang disebabkan oleh aktifitas warga urban. Permasalahan lingkungan memang kerap timbul sebagai imbas dari kehidupan manusia yang semakin moderen. 
Jurnal Pemikiran Sosiologi Volume 4 No. 1, Januari 2017

Adityo Nugroho

Komunitas Muda Urban Mengelola Sampah:

Kajian Partisipatoris Gerakan Peduli Sampah Nasional di Kota Yogyakarta

Dampak terhadap lingkungan seringkali terabaikan baik dalam proses industri ataupun konsumsi. Banyak proses industri dalam skala besar ataupun kecil yang masih mengesampingkan imbas kegiatan industrinya bagi lingkungan. Sementara itu masyarakat urban pun senantiasa tak ambil pusing akan dampak yang dihasilkan dari gaya hidup yang mereka lakukan. Salah satu isu lingkungan yang menonjol di daerah perkotaan adalah isu tentang sampah. Sampah sendiri pada dasarnya adalah material sisa dalam suatu proses, baik itu proses produksi (industri) ataupun konsumsi. Seiring berkembangnya jaman jumlah sampah bukannya berkurang, sebaliknya malah semakin tinggi. Ini terkait dengan manusia yang semakin moderen, gaya hidup yang semakin meninggalkan tradisi lama. Gaya hidup manusia moderen identik dengan produksi dan konsumsi barang yang sulit untuk terurai. Sisa proses inilah yang nantinya akan menjadi sampah.

Sampah menjadi salah satu ancaman bagi kota besar macam Yogyakarta. Setiap hari sampah semakin menggunung ditambah lagi dengan perilaku masyarakatnya yang belum sepenuhnya sadar akan bahaya sampah. Terkait sampah sebenarnya pemerintah telah menerbitkan UndangUndang Republik Indonesia Nomor 18 Tahun 2008 tentang Pengelolaan Sampah, isinya diantaranya bagi pemerintah daerah memiliki tugas untuk penyelenggaraan pengelolaan sampah yang baik serta berwawasan lingkungan. Wewenang yang diberikan adalah untuk menetapkan kebijakan dan strategi dalam pengelolaan sampah. Serta dijelaskan pula tentang peran serta masyarakat dalam pengelolaan sampah yang dilakukan oleh pemerintah daerah. Tapi sekali lagi UU tersebut hanyalah sebatas peraturan pemerintah semata. Permasalahannya apakah pemerintah daerah sudah menetapkan kebijakan dan strategi terkait pengelolaan. Jika sudah, apakah kebijakan tersebut hanya sekedar wacana atau sudah diterapkan di lapangan. Selanjutnya apakah kebijakan tersebut mendapat dukungan dan respon yang positif dari masyarakat sehingga mereka ikut berperan serta. Fakta di lapangan menunjukan bahwa sampah masih menjadi persoalan yang belum terselesaikan. Bagi kota Yogyakarta sampah masih menjadi persoalan masyarakat urban, maka mau tidak mau harus ada suatu gerakan bersama untuk mencoba mengurangi dampak yang ditimbulkan. Permasalahan sampah inilah yang membuat beberapa komunitas muda urban tergerak untuk melakukan suatu gerakan lingkungan terkait sampah. Beberapa komunitas muda urban saling bahu membahu untuk berkolaborasi melakukan tindakan nyata terkait permasalahan sampah. Adalah momen Hari Peduli Sampah Nasional yang jatuh pada tanggal 21 Februari menjadi pilihan untuk melakukan gerakan secara 
Jurnal Pemikiran Sosiologi Volume 4 No. 1, Januari 2017

Adityo Nugroho

Komunitas Muda Urban Mengelola Sampah:

Kajian Partisipatoris Gerakan Peduli Sampah Nasional di Kota Yogyakarta

kolektif. Kolaborasi antara komunitas muda urban ini menamakan diri Aliansi Komunitas Yogyakarta dan menamakan gerakan mereka dengan sebutan Peduli Sampah Nasional (PESAN).

\section{Metodologi dan Kerangka Teoritik Mengenai Gerakan Lingkungan}

Penelitian ini mengambil pendekatan studi kasus dan bersifat partisipatoris. Menurut Robert K Yin (2003) studi kasus merupakan sebuah cerita yang unik, spesial, atau menarik, kasus ini dapat berfokus pada suatu individu, organisasi, proses, lingkungan sekitar, institusi, dan kejadian sekitar. Hal yang dikaji dengan metode studi kasus dengan pendekatan partisipatoris ditujukan untuk menjelaskan mengapa suatu hal yang menarik tersebut dapat terjadi, bagaimana implementasinya, dan apa yang dihasilkan dari hal yang menarik tersebut. Pendekatan ini sesuai untuk menguak gerakan Peduli Sampah Nasional (PESAN) yang dinisiasi Aliansi Komunitas Yogyakarta. Akan dijelaskan kenapa gerakan ini dilakukan, seperti apa implementasinya di lapangan, serta dampak apa yang dihasilkan dari gerakan ini. Gerakan ini sendiri terdiri dalam dua tahap, yaitu yang pertama tanggal 18 Februari 2017 adalah kegiatan edukasi. Dalam kegiatan edukasi ini sendiri menyasar lima sekolah, yaitu SMA 7 Yogyakarta, SMA 9
Yogyakarta, SMA 1 Sentolo, SMA 1 Ngaglik, dan SMA 2 Ngaglik. Sedangkan kegiatan aksi pungut sampah dilakukan di bantaran Sungai Gajah Wong yang terletak di Kecamatan Umbulharjo.

Pemahaman akan gerakan lingkungan harus dimulai dari pengertian gerakan sosial yang nantinya berkembang menjadi gerakan sosial baru. Herbert Blumer (1951) mengartikan gerakan sosial sebagai aksi kolektif sejumlah besar orang untuk menciptakan tatanan kehidupan baru atau menggapai tujuan atau gagasan bersama. Sementara Giddens (1993) menyatakan bahwa gerakan sosial adalah suatu upaya kolektif untuk mengejar suatu kepentingan bersama, atau gerakan mencapai tujuan bersama melalui tindakan kolektif (collective action) di luar lingkup lembagalembaga yang mapan (Suharko, 2006). Gerry van Klinken (2007) mengkategorikan prinsip gerakan sosial dalam beberapa karakteristik. Dalam konsep ini, Klinken mengkategorikan lima poros dan paling tidak harus terdapat tiga poros diantaranya dalam suatu gerakan sosial. Kelima poros tersebut adalah harus ada tindakan kolektif, tujuan-tujuan atau klaim-klaim yang berorientasi pada suatu perubahan atau keteraturan, suatu tindakan kolektif yang bersifat ekstra institusional atau non institusional, organisasi sampai tingkat tertentu, dan keberlanjutan dalam hal waktu, sampai tingkat tertentu. 
Jurnal Pemikiran Sosiologi Volume 4 No. 1, Januari 2017

Adityo Nugroho

Komunitas Muda Urban Mengelola Sampah:

Kajian Partisipatoris Gerakan Peduli Sampah Nasional di Kota Yogyakarta

Sedangkan gerakan sosial baru atau new social movement merupakan dinamika dari gerakan sosial yang sudah ada lebih dahulu. GSB menurut Nash (2005) biasanya menekankan pada perubahan-perubahan dalam gaya hidup dan kebudayaan daripada mendorong perubahan-perubahan spesifik dalam kebijakan publik atau perubahan ekonomi sebagaimana tercermin dalam gerakan lingkungan, antiperang dan perdamaian, feminisme, dan sejenisnya. Menurut Singh (2001) bahwa gerakangerakan lingkungan, feminisme, hak asasi manusia, perdamaian, dan sebagainya yang biasa dirujuk sebagai bagian dari GSB terus berlangsung baik di negara-negara maju maupun negara-negara berkembang (Suharko, 2006). Gerakan Sosial Baru dibedakan dari gerakan kelompok kepentingan yang hanya merepresentasikan kelompok kecil dalam memperjuangkan kepentingan sempit, dan juga berbeda dari gerakan politik, seperti partai politik, yang bertujuan pada transformasi sosial melalui proses politik. GSB ini misalnya adalah gerakan kaum feminis, pembela lingkungan, dan kulit hitam (Abercrombie dkk, 2010). Lebih lanjut gerakan sosial baru dikenali dengan empat ciri-cirinya. Tujuan, gerakan ini lebih cenderung kearah perubahan nilainilai sosial dan budaya baru, khususnya yang prihatin terhadap otonomi individual, daripada transformasi struktur sosial sebagai suatu keatuan. Basis sosial, gerakan politik tradisional berbasis pada kelas sosial, gerakan sosial baru didasarkan pada kelompok yang lain, seperti perempuan. Perangkat aksi, gerakan sosial baru tidak menggunakan perangkat politik tradisional untuk mempengaruhi negara tetapi bergantung pada mobilisasi massa untuk mengubah nilai dan sikap, sebagaimana di dalam pengaturan gerakan sosial "hijau". Organisasi, gerakan sosial baru menolak model organisasi birokratik dan resmi, dan lebih menyukai model organisasi yang longgar dan luwes yang secara aktif melibatkan anggota-anggota awam.

Gerakan lingkungan sendiri merupakan salah satu bentuk dari gerakan sosial baru. Gerakan lingkungan dilandasi oleh semakin meluasnya krisis lingkungan hidup yang disertai dengan tumbuhnya kesadaran masyarakat akan pentingnya menjaga lingkungan hidup. Menurut sejumlah pakar sosiolog lingkungan di Amerika Serikat (AS) gerakan lingkungan di setiap negara dapat dibagi ke dalam tiga komponen (Aditjondro, 2003). Public environmentalist, yakni para warga khalayak ramai yang berusaha memperbaiki kondisi lingkungan sekitar, langsung lewat tindakan-tindakan dan sikap mereka masing-masing. Organized environmentalist atau voluntary environmentalist, yakni mereka yang bergerak melalui organisasi-organisasi yang khusus didirikan untuk berusaha memperbaiki lingkungan hidup mereka, yang kadang sampai melintasi batas negara. 
Jurnal Pemikiran Sosiologi Volume 4 No. 1, Januari 2017

Adityo Nugroho

Komunitas Muda Urban Mengelola Sampah:

Kajian Partisipatoris Gerakan Peduli Sampah Nasional di Kota Yogyakarta

Institusional environmental movement organization, yakni mereka yang bergerak melalui birokrasi-birokrasi resmi yang mengklaim diri punya kewenangan terhadap masalah-masalah lingkungan.

Menurut Schusler \& Krasny (2010) terdapat 5 bentuk tindakan lingkungan yang menjadi fokus atau penekanan gerakan lingkungan. Pertama, perbaikan lingkungan fisik (physical environmental improvement). Aksinya berupa upaya pemulihan atau restorasi suatu habitat alam tertentu, taman kota, sungai, dan lingkungan fisik lainnya. Kedua, pendidikan lingkungan (environmental education). Aksinya terwujud dalam aktivitas seperti pengorganisasian festival komunitas dan pameran informasi, produksi media melalui newsletter, brosur, pamflet, video, dan media-media penyampai pesan pendidikan lainnya. Ketiga, terkait penelitian (inquiry). Bentuk nyata dari aksi ini adalah community assessments, survei dan pemetaan, monitoring lingkungan, eksperimen ilmiah yang didesan untuk menginformasikan atau mengevaluasi suatu tindakan, dan kegiatan berbasis riset ilmiah lainnya. Keempat, analisis isu publik dan advokasi untuk perubahan kebijakan. Aksi ini berkaitan dengan dampak lingkungan yang (akan) terjadi sebagai konsekuensi dari pilihan dan implementasi kebijakan publik tertentu oleh pemerintah. Tindakan yang dilakukan antara lain meneliti dan menganalisis dampak lingkungan dari peraturan tentang pembuangan limbah cair ke tempat tertentu (misalnya, sungai, laut, danau dan lain-lain) dan memberikan rekomendasi kebijakan kepada komite legislatif. Kelima, upaya menghasilkan produk atau layanan yang memiliki kontribusi kepada pengembangan komunitas (community development). Aksiaksinya berupa tindakan mengembangkan produk makanan tertentu berbasis sumberdaya lokal dan memiliki nilai tambah bagi warga komunitas (Suharko dkk, 2014).

Terkait krisis dan bencana lingkungan hidup yang sudah mendunia, Keraf (2010) secara kasar membedakan ke dalam lima macam, diantaranya kerusakan lingkungan hidup, pencemaran lingkungan hidup, kepunahan sumber daya alam dan lingkungan hidup, kekacauan iklim global, dan masalah sosial terkait dampak lingkungan hidup. Dalam pencemaran lingkungan hidup atau polusi terdapat empat jenis, yaitu polusi udara, polusi air, polusi laut, dan sampah.

\section{Analisis Kajian Partisipatoris: Komunitas Muda Urban Berkolaborasi Mengelola Sampah}

Awalnya ide untuk melakukan gerakan lingkungan terkait sampah hanya digulirkan oleh beberapa komunitas saja dengan mengambil tajuk gerakan berupa Peduli Sampah Nasional (PESAN). Momentum 
Jurnal Pemikiran Sosiologi Volume 4 No. 1, Januari 2017

Adityo Nugroho

Komunitas Muda Urban Mengelola Sampah:

Kajian Partisipatoris Gerakan Peduli Sampah Nasional di Kota Yogyakarta

gerakan ini menyesuaikan dengan peringatan Hari Peduli Sampah Nasional yang jatuh pada tanggal 21 Februari. Hari Peduli Sampah Nasional sendiri merupakan peringatan tragedi longsornya tumpukan sampah di TPA Leuwigajah pada tanggal 21 Februari 2005. Seperti dikutip dari Kompas.com (21 Februari 2011), persis di hari Senin tepatnya pukul 02.00 dinihari saat tumpukan sampah di TPA Leuwigajah longsor. Datang bak gelombang tsunami, sampah anorganik berupa plastik, gabus, kayu, hingga sampah organik menghantam dua pemukiman yakni Kampung Cilimus dan Kampung Pojok. Pemukiman yang penuh kehidupan itu langsung luluh lantak tertimbun sampah meski berjarak satu kilometer lebih dari puncak tumpukan sampah. Gunungan sampah sepanjang 200 meter dan setinggi 60 meter itu goyah karena diguyur hujan deras semalam suntuk dan terpicu konsentrasi gas metan dari dalam tumpukan sampah. Sampah di TPA itu memang menggunakan sistem open dumping yakni dibuang dan ditumpuk begitu saja. Akibat kejadian tersebut, tercatat 157 orang meninggal dunia, belum termasuk harta benda yang lain. Inilah musibah yang barangkali tercatat pertama kali dalam sejarah peradaban manusia, ratusan nyawa melayang gara-gara tertimbun sampah.

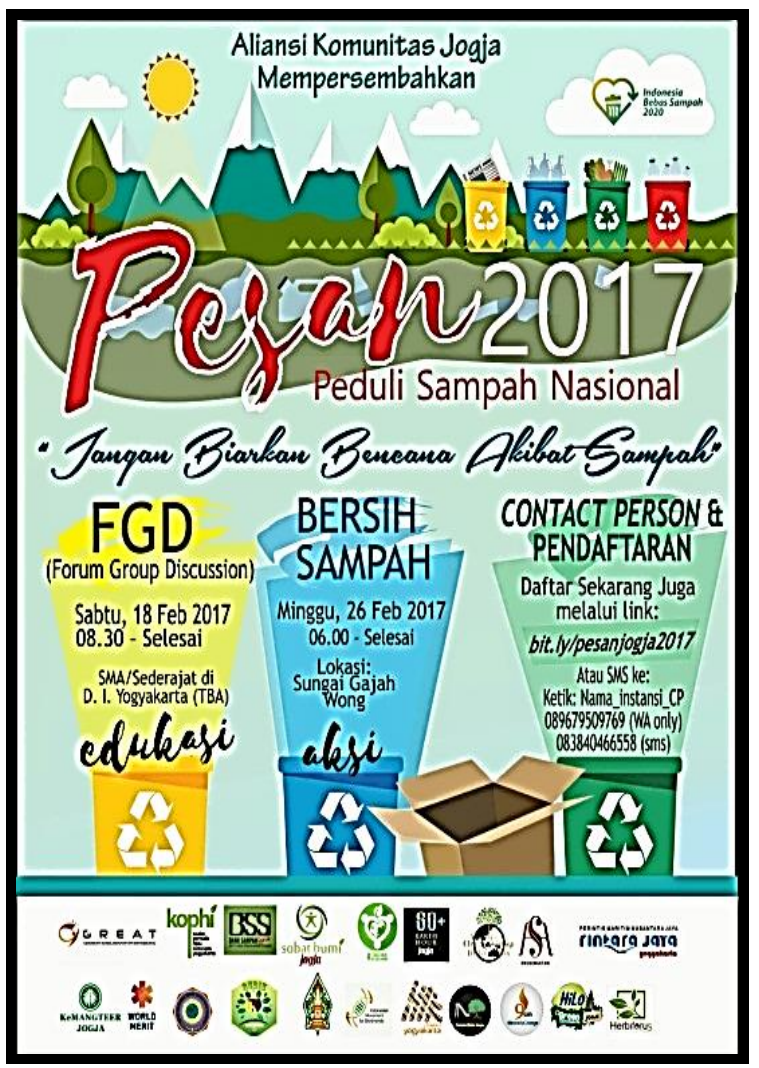

Gambar 1. Poster Kegiatan Peduli Sampah Nasional (PESAN) 2017 (Sumber: Dokumentasi Panitia PESAN 2017- Arsip koleksi penulis)

Peringatan atas momentum itulah yang menjadi ide dilakukannya gerakan Peduli Sampah Nasional (PESAN) 2017. Setelah ide dipublikasikan kepada komunitas muda urban lain maka terkumpul 20 komunitas yang menjadi pioner gerakan ini. Komunitas itu antara lain KOPHI Yogyakarta, World Merit Yogyakarta, Earth Hour (EH) Yogyakarta, Kemangteer Yogyakarta, Great Yogyakarta, Together We Save Energy (TWSE), Youth For Climate Change (YFCC) Yogyakarta, Hillo Green Community, Herbiforus, Bank Sampah Syariah (BSS), IMTLI (Ikatan Mahasiswa Teknik Lingkungan Indonesia), Sobat Bumi 
Jurnal Pemikiran Sosiologi Volume 4 No. 1, Januari 2017

Adityo Nugroho

Komunitas Muda Urban Mengelola Sampah:

Kajian Partisipatoris Gerakan Peduli Sampah Nasional di Kota Yogyakarta

Yogyakarta, Komunitas Untuk Yogyakarta (KUJ), Taman Kota Yogyakarta, Solidaritas Alam Yogyakarta (Salam), 9 CM, ISYF Yogyakarta, Rintara Jaya Yogyakarta, Greenpack, dan Padepokan ASA. Sampai akhirnya kesemua komunitas muda urban ini menamakan kolaborasi mereka sebagai Aliansi Komunitas Yogyakarta. Kolaborasi merupakan salah satu upaya kolektif untuk mencapai kepentingan bersama, salah satu falsafah gerakan sosial. Upaya kolektif ini menuntut aktor-aktornya untuk memanfaatkan sumber daya yang dimiliki serta meminimalisir halangan atau dampak dalam upaya mencapai tujuan gerakan lingkungan. Kolaborasi meraka jadikan pilihan sebagai upaya untuk membuat gerakan ini menjadi lebih besar daripada menginisiasi gerakan secara mandiri. Dengan adanya banyak komunitas yang terlibat maka sumber daya manusia untuk melakukan gerakan menjadi semakin besar pula. Perwakilan anggota dari berbagai komunitas muda urban ini berkolaborasi membentuk satu kepanitiaan yang akan membawahi acara yang akan mereka inisiasi. Kepanitiaan ini berfungsi untuk mengkoordinasikan acara, melakukan koordinasi dengan pihak terkait, surat menyurat, menyiapkan perlengkapan, dokumentasi acara, sampai pada penyiapan konsumsi. Seperti diketahui bahwa dalam suatu gerakan maka butuh pendanaan. Mengingat gerakan ini murni gerakan sosial maka mereka memilih untuk tidak tergantung pada sponsorship, lebih memilih untuk menanggung beban pendanaan secara bersama-sama dalam bentuk iuran antar komunitas. Pilihan ini sebagai langkah untuk tetap menjaga kemurnian gerakan lingkungan yang sedang mereka garap. Menarik jika kita melihat sisi voluntary yang dilakukan para komunitas muda urban ini. Mereka menyisihkan waktu untuk melakukan suatu gerakan, mereka menawarkan tenaga untuk mengurusi berjalannya gerakan, serta mereka pun dikenakan kewajiban iuran untuk mendanai gerakan. Terasa mustahil jika tanpa ada kepedulian yang kuat akan lingkungan hidup.

Tercatat membutuhkan sampai tiga kali rapat besar untuk menentukan bahwa Aliansi Komunitas Yogyakarta akan melakukan gerakan lingkungan dalam dua tahap. Edukasi dilakukan pada tanggal 18 Febuari 2017 yang akan menyasar Sekolah Menengah Atas di Yogyakarta dan sekitarnya. Sedangkan Aksi direncanakan pada 26 Februari 2017 dengan target pungut sampah di sepanjang bantaran Sungai Gajah Wong. Selain rapat besar, mereka menggunakan aplikasi sosial media sebagai wadah untuk berkomunikasi seluruh anggota. 
Jurnal Pemikiran Sosiologi Volume 4 No. 1, Januari 2017

Adityo Nugroho

Komunitas Muda Urban Mengelola Sampah:

Kajian Partisipatoris Gerakan Peduli Sampah Nasional di Kota Yogyakarta

\section{Edukasi Lingkungan dan Pengelolaan} Sampah di Sekolah

Pendidikan lingkungan hidup menurut UNESCO pada Deklarasi Tbilisi tahun 1977 adalah suatu proses untuk membangun populasi manusia di dunia yang sadar dan peduli terhadap lingkungan total (keseluruhan) dan segala masalah yang berkaitan dengannya, dan masyarakat yang memiliki pengetahuan, ketrampilan, sikap dan tingkah laku, motivasi serta komitmen untuk bekerja sama, baik secara individu maupun secara kolektif, untuk dapat memecahkan berbagai masalah lingkungan saat ini, dan mencegah timbulnya masalah baru.

Menurut US EPA, pendidikan lingkungan adalah suatu proses yang memnungkinkan para individu untuk menjelajahi isu-isu lingkungan, melibatkan diri dalam pemecahan masalah, dan mengambil tindakan untuk memperbaiki lingkungan. Sebagai hasilnya, para individu mengembangkan suatu pemahaman yang lebih mendalam tentang isu-isu lingkungan dan memiliki keahlian untuk membuat keputusan yang memadai dan dapat dipertanggungjawabkan (Suharko dkk, 2014). Pendidikan lingkungan sendiri mencakup lima komponen utama, yaitu kesadaran dan kepekaan terhadap lingkungan dan tantangan lingkungan, pengetahuan dan pemahaman terhadap lingkungan dan tantangan lingkungan, sikap peduli terhadap lingkungan dan motivasi untuk memperbaiki atau memelihara kualitas lingkungan, keahlian untuk mengidentifikasi dan membantu menghadapi tantangan lingkungan, serta partisipasi dalam aktivitas yang mengarah ke resolusi terhadap tantangan lingkungan.

Nomura dan Hendarti

(2005) mengungkapkan bahwa pendidikan lingkungan dapat disampaikan melalui tiga tipe cara. Pertama, pendidikan formal yang diselenggarakan oleh sekolah-sekolah, perguruan tinggi, dan lembaga-lembaga pemerintah yang memiliki kewenangan untuk itu. Kedua, pendidikan non-formal yaitu pendidikan yang diorganisasikan tidak melalui sekolah formal atau pelembagaan. Pengetahuan, keahlian, dan nilai-nilai diajarkan oleh keluarga, teman, atau anggota-anggota suatu komunitas. Secara umum pendidikan non-formal ini biasanya dilakukan oleh organisasi-organisasi nonpemerintah (NGO) yang peduli pada lingkungan. Ketiga, pendidikan informal yaitu pendidikan sehari-hari dan terus menerus dari pengalaman hidup diluar pendidikan formal dan non-formal yang terorganisasikan. Ini mencakup pembelajaran dalam keluarga, tempat kerja, dan kehidupan sosial. Jika menilik pada klasifikasi di atas, maka edukasi lingkungan yang dilakukan oleh Aliansi Komunitas Yogyakarta merupakan jenis edukasi nonformal karena diinisiasi oleh komunitas, 
Jurnal Pemikiran Sosiologi Volume 4 No. 1, Januari 2017

Adityo Nugroho

Komunitas Muda Urban Mengelola Sampah:

Kajian Partisipatoris Gerakan Peduli Sampah Nasional di Kota Yogyakarta

walaupun tetap untuk lokasi edukasi berada di sekolah.

Kegiatan edukasi sekolah menyasar lima Sekolah Menengah Atas (SMA), yaitu SMA 7 Yogyakarta, SMA 9 Yogyakarta, SMA 1 Sentolo, SMA 1 Ngaglik, dan SMA 2 Ngaglik. Menarik ketika sebenarnya sekolah merupakan institusi pendidikan namun materi bidang lingkungan masih dianak tirikan. Institusi pendidikan formal masih terfokus pada mata pelajaran pokok seperti Matematika, Bahasa Indonesia, Bahasa Inggris, dan sejenisnya. Pendidikan lingkungan hanya diajarkan dengan konsep pengintegrasian, yaitu sekedar disisipkan oleh para guru dalam pengajaran mata pelajaran pokok. Proses pendidikan lingkungan pada tingkat siswa sekolah ini dilakukan dengan konsep pendidikan yang menyenangkan dan tidak membebani para siswa. Siswa diberi materi terlebh dahulu tentang bahaya sampah bagi kehidupan. Setelah itu mereka diajak serta untuk berperan aktif dalam sebuah Focus Group Discussion (FGD) terkait pengelolaan sampah yang didampingi oleh anggota Aliansi Komunitas Yogyakarta. Dalam FGD ini para siswa dibagi menjadi beberapa kelompok yang masing-masing berperan sebagai pemerintah, pihak swasta, masyarakat, dan pelajar. Nantinya hasil FGD masing-masing kelompok harus dipresentasikan dalam bentuk gambar dan lisan. Secara konsep memang sederhana, tapi dalam prakteknya ternyata sangat luar biasa. Siswa diberi kesempatan untuk mengeluarkan ide-idenya terkait pengelolaan sampah.

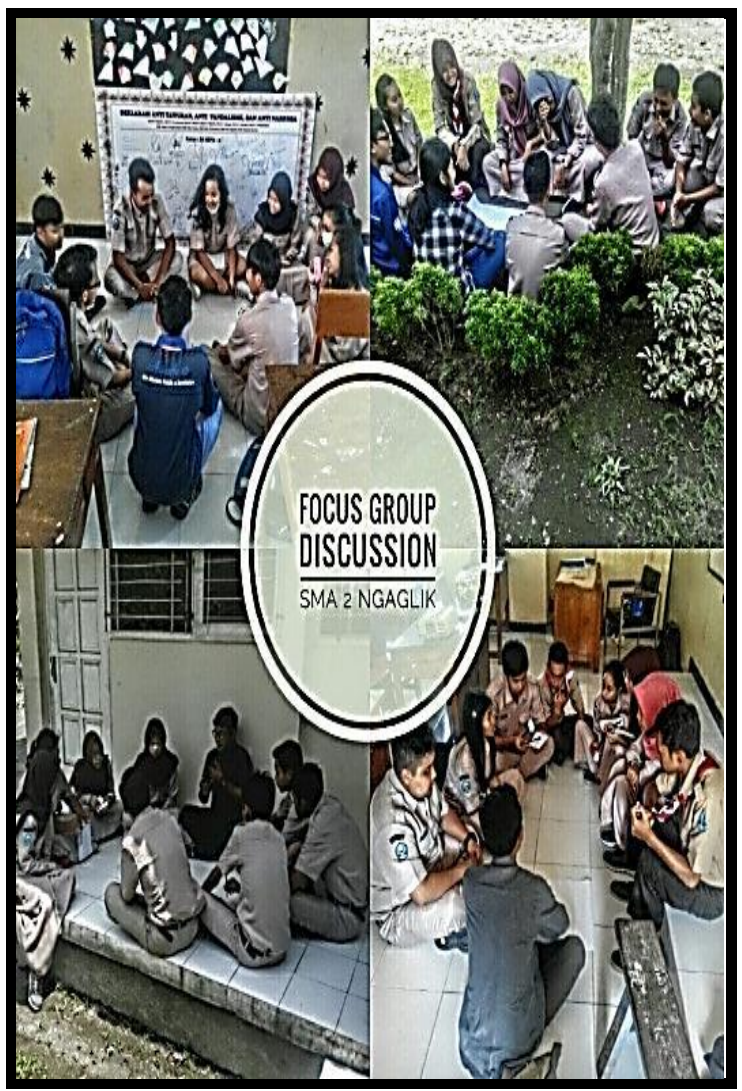

Gambar 2. Kegiatan FGD Peserta Edukasi Lingkungan di SMA 2 Ngaglik

(Sumber: Dokumentasi Panitia PESAN 2017- Arsip koleksi penulis)

Sebagai contoh FGD yang dilakukan di SMA 2 Ngaglik, peserta sangat antusias dalam melakukan diskusi dan presentasi. Mereka yang berperan menjadi pemerintah berusaha untuk membuat kebijakan pengelolaan sampah beserta strategi dalam mensosialisasikan kepada masyarakat dan pihak swasta. Pihak swasta berupaya semaksimal mungkin menekan produksi sampah tanpa mengurangi kegiatan industri mereka. Salah satunya dilakukan dengan 
Jurnal Pemikiran Sosiologi Volume 4 No. 1, Januari 2017

Adityo Nugroho

Komunitas Muda Urban Mengelola Sampah:

Kajian Partisipatoris Gerakan Peduli Sampah Nasional di Kota Yogyakarta

membuat kebijakan terkait sampah kepada para pekerjanya serta pemanfaatan kembali sampah hasil industri agar memiliki nilai guna dan jual, bekerjasama dengan masyarakat sekitar pabrik atau tempat usaha dilakukan. Masyarakat sendiri berupaya untuk meminimalisir sampah yang mereka hasilkan, dengan cara memperbaiki pola hidup dan mengolah sampah menjadi memiliki nilai guna, semisal kompos dari sampah organik dan hiasan rumah dari sampah non organik. Sedangkan pihak pelajar mencoba untuk menerapkan pengelolaan sampah dari lingkungan terdekat mereka, yaitu sekolah. Diawali dengan membuang sampah pada tempatnya sesuai kategori sampah, sampai pada pemanfaatan sampah untuk menjadi benda kerajinan tangan.

Pemikiran-pemikiran tersebut adalah hasil dari diskusi yang dilakukan oleh para pelajar. Maka kesadaran akan pentingnya pengelolaan sampah didapat para pelajar bukan hanya dari materi yang disampaikan oleh Aliansi Komunitas Yogyakarta, melainkan juga atas dasar pemikiran pribadi yang didiskusikan bersama. Caracara seperti inilah yang mungkin jarang didapat oleh pelajar dalam kegiatan belajar mengajar di sekolah. Gerakan edukasi yang dilakukan oleh Aliansi Komunitas Yogyakarta lebih mudah untuk diterima para pelajar, selain cara penyampaian lebih dinamis juga ditunjang dengan penampilan dan umur para pemateri dan pemantik diskusi yang tidak terlalu jauh dari para peserta. Dari lima sekolah yang menjadi target gerakan edukasi tidak ada yang mendapat respon negatif dari pelajar atau bahkan pengelola sekolah. Bagi mereka kegiatan seperti ini menjadi semacam penyegaran pengetahuan dan belajar bagi masing-masing sekolah yang bersangkutan.

\section{Aksi Bersih Sampah di Kali Gajah Wong}

Selain pendidikan lingkungan, Schusler \& Krasny (2010) mengemukakan bahwa fokus gerakan lingkungan adalah perbaikan lingkungan fisik (physical environmental improvement). Kegiatannya berupa aksi restorasi suatu habitat alam tertentu, termasuk sungai. Selain Kali Code, salah satu sungai besar yang membelah Yogyakarta adalah Kali Gajah Wong. Asal usul sungai ini sendiri berasal dari abad ketujuhbelas, ketika ada gajah dan orang hanyut ditelan derasnya aliran air wilayah ini. Untuk mengenangnya maka Sultan yang memerintah pada waktu itu menamakan aliran air ini sebagai Kali Gajah Wong. Seiring berkembangnya area perkotaan dan semakin sempitnya lahan hunian maka bantaran Kali Gajah Wong juga dimanfaatkan masyarakat menjadi tempat tinggal. Dan seperti yang diduga, letak pemukiman yang berada di pinggiran sungai ditambah perilaku peduli lingkungan masyarakat masih rendah membuat daerah ini rawan kebanjiran. Jika intensitas hujan 
Jurnal Pemikiran Sosiologi Volume 4 No. 1, Januari 2017

Adityo Nugroho

Komunitas Muda Urban Mengelola Sampah:

Kajian Partisipatoris Gerakan Peduli Sampah Nasional di Kota Yogyakarta

di Yogyakarta tinggi maka pemukiman sepanjang Kali Gajah Wong bisa dipastikan banjir. Ditambah dengan banyaknya sampah yang ada di sungai ataupun pinggiran sungai itu sendiri.

Atas pertimbangan-pertimbangan itulah Aliansi Komunitas Yogyakarta memutuskan untuk memilih Kali Gajah Wong sebagai lokasi aksi bersih sampah. Sebenarnya kalau melihat pada sisi publisitas gerakan akan lebih terlihat jika pemilihan lokasi berada di keramaian seperti sepanjang Malioboro, titik Nol Kilometer, ataupun Alun-alun. Hanya saja pilihan mereka bukan dari sisi publisitas, tapi bagaimana aksi bersih sampah ini mampu memberikan hasil yang nyata di lapangan. Dari berbagai survei tempat yang dilakukan akhirnya memilih bantaran Kali Gajah Wong untuk menjadi lokasi aksi bersih sampah. Karena lokasi yang merupakan area pemukiman warga maka Aliansi Komunitas Yogyakarta juga turut mengajak kerja sama elemen warga sekitar. Selain itu mereka juga membuka kesempatan bagi relawan lain yang ingin bergabung dalam aksi bersih sampah, hasilnya ratusan relawan mendaftar dan ikut hadir di lokasi aksi.

Aksi sendiri mengambil tempat parkiran Universitas Cokroaminoto Yogyakarta (UCY) sebagai titik kumpul. Tepat pada jam 07.00 pagi tanggal 26 Februari 2017 berkumpul Aliansi Komunitas Yogyakarta, para relawan, dan juga beberapa perwakilan warga. Setelah briefing dan pembagian kelompok mereka bergerak menuju titik-titik yang sudah ditentukan. Aksi bersih sampah dimulai dari wilayah pemukiman warga yang berdekatan dengan Kali Gajah Wong, dilanjutkan sampai ke pinggiran sungai yang merupakan konsentrasi sampah terbanyak. Banyaknya sampah yang berada di pinggiran sungai sebagai dampak dari kurangnya kepedulian masyarakat sekitar akan pengelolaan sampah yang baik. Di sisi lain sampahsampah ini merupakan kiriman dari hulu sungai yang terbawa sampai ke hilir, setiap banjir terjadi maka sampah akan selalu menumpuk di sekitaran pemukiman warga.

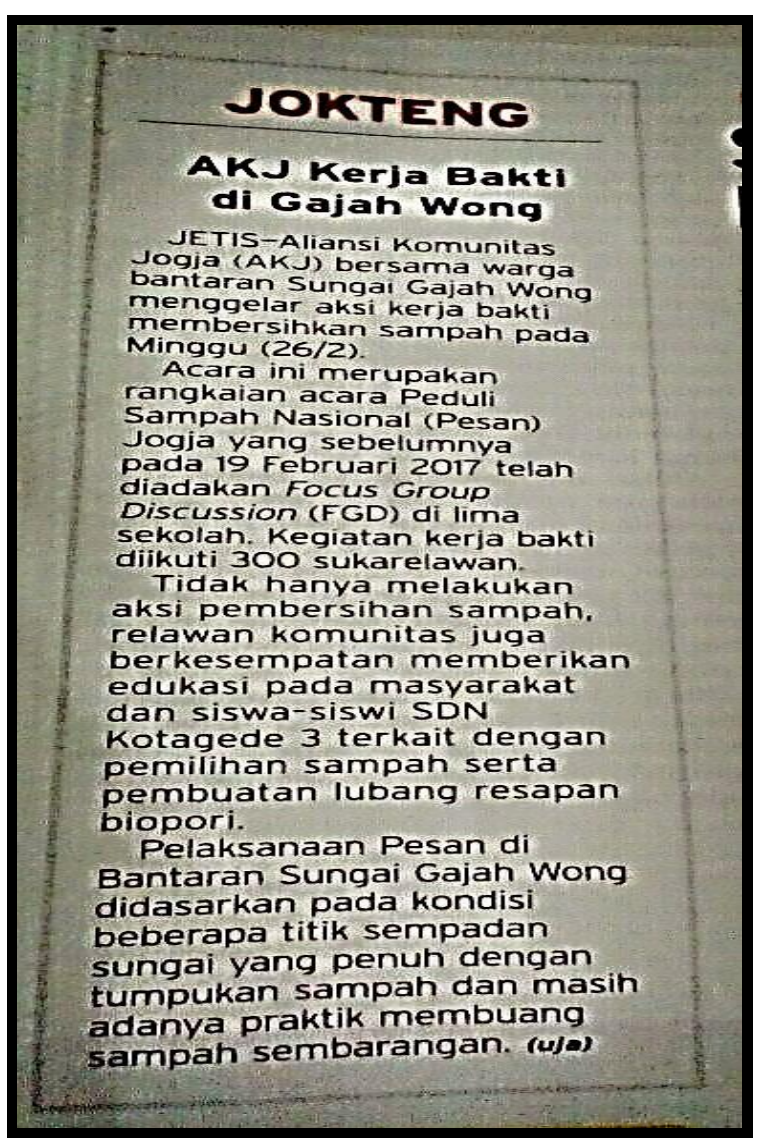

Gambar 3. Publikasi Aksi Bersih Sampah di salah satu koran lokal (Sumber: Dokumentasi Panitia PESAN 2017- Arsip koleksi penulis) 
Jurnal Pemikiran Sosiologi Volume 4 No. 1, Januari 2017

Adityo Nugroho

Komunitas Muda Urban Mengelola Sampah:

Kajian Partisipatoris Gerakan Peduli Sampah Nasional di Kota Yogyakarta

Aksi lingkungan hidup menurut Jensen \& Schnack (1997) bisa dilakukan dalam bentuk aksi lingkungan langsung (direct environmental action) dan aksi lingkungan tidak langsung (indirect environmental action). Aksi langsung dilakukan dengan memberikan kontribusi langsung untuk menjaga lingkungan atau mengatasi permasalahan lingkungan, seperti pemanfaatan taman kota, pembersihan sungai, dan lain-lain. Aksi lingkungan langsung inilah yang diinisiasi Aliansi Komunitas Yogyakarta. Dengan adanya aksi langsung maka mereka dapat langsung memberikan dampak bagi masyarakat. Paling tidak memberikan kesadaran betapa pentingnya pengelolaan sampah bagi kehidupan. Di sisi lain memperlihatkan bahwa kaum muda kota yang terafiliasi dalam beberapa komunitas muda urban tak hanya tinggal diam ketika melihat kerusakan lingkungan yang ditimbulkan dari adanya sampah.

\section{Kesimpulan}

Kegiatan edukasi dan aksi lingkungan yang diinisiasi oleh Aliansi Komunitas Yogyakarta ini menunjukan bahwa kaum muda urban cenderung aktif dalam merespon fenomena di sekitarnya. Tentunya hal ini berbalik dengan stigma negatif yang belakangan ini disematkan kepada kaum muda urban Yogyakarta. Di luar banyaknya aksi kenalakan remaja dan maraknya tindak pidana klithih, masih banyak anak muda yang memilih tindakan positif untuk bergerak peduli pada lingkungan. Mereka yang tergabung dalam komunitas muda urban yang menginisiasi acara Peduli Sampah Nasional (PESAN) 2017 tentunya patut berbangga bahwa pilihan mereka akan komunitasnya adalah tepat.

Aksi kolektif dalam bentuk kolaborasi antar komunitas muda urban tentunya memiliki kisah tersendiri. Jika kita menilik pada isu lingkungan hidup maka pastinya tiap komunitas muda urban memiliki pandangan tersendiri atas bagaimana harus bersikap. Cukup tidak membuang sampah sembarang, mengajak orang lain untuk melakukan pola hidup sehat, kegiatan turun langsung ke pusat kerusakan lingkungan, atau bahkan sampai memilih menjadi vegetarian. Tiap komunitas muda urban berhak atas klaim bagaimana berkontribusi dalam pelestarian lingkungan. Maka menjadi luar biasa ketika komunitas yang tergabung dalam Aliansi Komunitas Yogyakarta ini mengesampingkan ego komunitas masing-masing dan bersama menginisiasi suatu gerakan. Suatu sikap dewasa yang ditunjukan oleh para komunitas muda urban.

Terkait isu dan pilihan gerakan, Keraf (2010) juga menyatakan bahwa ada beberapa opsi yang bisa dilakukan untuk menghentikan atau setidaknya 
Jurnal Pemikiran Sosiologi Volume 4 No. 1, Januari 2017

Adityo Nugroho

Komunitas Muda Urban Mengelola Sampah:

Kajian Partisipatoris Gerakan Peduli Sampah Nasional di Kota Yogyakarta

menghambat laju krisis dan bencana lingkungan hidup, yaitu perubahan cara pandang dan perilaku, perubahan paradigma dan kebijakan pembangunan, beralih ke industri bersih, tata kelola lingkungan hidup yang baik, penguatan dan pelurusan desentralisasi, dan aksi nyata. Aksi nyata merupakan suatu tindakan baik sendiri ataupun kolektif sebagai wujud komitmen dan kepedulian terhadap lingkungan hidup. Di sinilah daya kreatif para kaum muda muncul, dengan keterbatasan sumber daya dapat memilah jenis gerakan yang sesuai dengan kemampuan. Edukasi ke Sekolah Menengah Atas (SMA) dilakukan sebagai bagian untuk mengubah cara pandang dan perilaku. Sedangkan bersih sampah di Kali Gajah Wong merupakan aksi nyata secara kolektif dalam kepedulian terhadap lingkungan.

\section{Daftar Pustaka}

Abercrombie, Nicholas, et. al., 2010. Kamus Sosiologi. Yogyakarta: Pustaka Pelajar. Aditjondro, George Junus. 2003. Pola-pola Gerakan Lingkungan, Refleksi untuk Menyelamatkan Lingkungan dari Ekspansi Modal. Yogyakarta: Pustaka Pelajar.

Creswell, John W. 2012.. Research Design: Pendekatan Kualitatif, Kuantitatif, dan Mixed. Yogyakarta: Pustaka Pelajar.

Giddens, Anthony. 1993. Sociology. Cambridge: Polity Press.
Joga, Nirwono. 2013. Gerakan Kota Hijau. Jakarta: PT Gramedia Pustaka Utama.

Keraf, A. Sonny. 2010. Krisis dan Bencana Lingkungan Hidup Global. Yogyakarta: Kanisius.

Klinken, Gerry Van. 2007. Perang Kota Kecil. Jakarta: Yayasan Obor.

Nomura, Ko, \& Hendarti, Latipah (ed). 2005. Environmental Education and NGOs in Indonesia. Jakarta: Yayasan Obor Indonesia.

Suharko, et. al., 2014. Organisasi Pemuda Lingkungan di Indonesia Pasca-Orde Baru. Yogyakarta: Gadjah Mada University Press.

Suharko. 2005. Merajut Demokrasi, Hubungan NGO, Pemerintah, dan Pengembangan Tata Pemerintahan Demokratis (1966-2001). Yogyakarta: Tiara Wacana.

Yin, Robert K. 2003. Case Study Research (Design and Methods, 3 ed.). London: SAGE publication.

Jurnal:

Suharko. Gerakan Sosial Baru di Indonesia: Repertoar Gerakan Petani. JSP Volume 10, Nomor 1, Juli 2006.

Suharko. Pencegahan Bencana Lingkungan Hidup Melalui Pendidikan Lingkungan. Jurnal Manusia dan Lingkungan Volume 21, Nomor 2, Juli 2014.

Sumber Internet:

http://regional.kompas.com/read/2011/02 /21/20382467/Leuwigajah.Kami.Tak kan.Lupa 